\title{
Relationship between Age and Enzymatic Activities in Human Erythrocytes from Normal and Fava Bean-sensitive Subjects *
}

\author{
A. Bonsignore, G. Fornaini, A. Fantoni, G. Leoncini, and P. Segni \\ (From the Istituto di Chimica Biologica dell' Università di Genova, Genoa, Italy)
}

This paper is concerned with the relation between metabolic behavior and cell age in erythrocytes of normal subjects and in erythrocytes of fava bean-sensitive subjects in the nonhemolytic, the hemolytic, and the posthemolytic periods.

That as red cells age there is a progressive decrease in the activity of several enzymes has been well established in vivo. The relationship between the age of erythrocytes and their enzymatic activities is of special interest in subjects with drug-induced or fava bean-induced hemolytic anemias. Recent studies have demonstrated that the mean age of erythrocytes of Negro subjects with glucose-6-phosphate dehydrogenase (G-6-PD) deficiency is diminished on the average $25 \%(1,2)$. During acute hemolytic episodes in such subjects, it is the older erythrocytes which preferentially lyse (3-5).

It has been suggested that a relative resistance to hemolysis of young red blood cells is related to their more active metabolism and in particular to their higher levels of glucose-6-phosphate dehydrogenase. Studies primarily in Negroes have demonstrated that the level of glucose-6-phosphate dehydrogenase in young compared to old red cells of subjects with hereditary glucose-6phosphate dehydrogenase deficiency is significantly higher than the whole cell population although not comparable to normal values (4-8).

Among Sardinian subjects with hereditary deficiency of glucose-6-phosphate dehydrogenase, we have studied this activity and a variety of other enzymes and metabolic parameters of eryth-

* Submitted for publication April 11, 1963; accepted December 26, 1963.

This work was supported by grant HE 04586 of the U. S. Public Health Service.

Preliminary communications concerning some of the results reported in this paper have appeared in Boll. Soc. ital. Biol. sper. 1962, 38, 1027, 1030. rocytes before, during, and after acute hemolytic episodes caused by exposure to fava beans.

In striking contrast to the findings reported for glucose-6-phosphate dehydrogenase activity in erythrocytes during the drug-induced posthemolytic episodes in Negro subjects, the activity of the glucose-6-phosphate dehydrogenase did not increase among the Caucasian population that we studied. In addition, the activities of methemoglobin reductase, transketolase (TK), and transaldolase (TA) were higher in erythrocytes of subjects who had a history of favism but who were now in a nonhemolytic period. The reduced glutathione (GSH) content and the reduced glutathione stability in the presence of acetylphenylhydrazine did not vary with erythrocyte age in normal subjects, but in fava beansensitive subjects they had higher levels in young erythrocytes than in old cells in the nonhemolytic period. The reduced glutathione content and stability during the posthemolytic period were within normal levels.

\section{Methods}

Subjects. The normal subjects included 18 males ranging in age between 3 and 45 years without history or other evidence of hemolytic episodes. The experiments during the nonhemolytic periods were performed on 16 male subjects, born in Sardinia or coming from a Sardinian family, varying in age between 4 and 49 years and with a history of at least one hemolytic crisis caused by fava beans. The subjects studied for the hemolytic and the posthemolytic periods were 8 male Sardinians, 7 of them from ages 2 to 8 , and one 70 years old.

Separation of young and old erythrocytes. The resuspended washed erythrocytes (to be referred to as the "whole erythrocyte population," WEP) were separated into fractions of relatively young and old cells by two different methods. 1) The method of Marks and Johnson for serial osmotic hemolysis is based on the principle that young red cells are more resistant to hypotonic hemolysis than are older cells $(9)$. 2) In the 
centrifugation procedure of Marks and Gross (6), the younger erythrocytes, being less dense, sediment less rapidly and will be at the top of the column of packed cells.

Ensyme determination.: Glucose-6-phosphate dehydrogenase (G-6-PD) and 6-phosphogluconate dehydrogenase (6-P-GD) determinations were performed according to Kornberg and Horecker (10) and Horecker and Smyrniotis (11), following Glock and McLean's suggestions to remove the glucose-6-phosphate dehydrogenase interference on 6-phosphogluconate derived from glucose-6-phosphate (12).

Glutathione reductase and methemoglobin reductase activities, transketolase, and transaldolase were assayed spectrophotometrically by methods previously described $(13,14)$. With a spectrophotometric determination of the charge of the optical density at $340 \mathrm{~m} \mu$, reduced triphosphopyridine nucleotide (NADPH) and reduced diphosphopyridine nucleotide $(\mathrm{NADH})$ were oxidized in the presence of oxidized glutathione. Methemoglobin reductase activity was assayed at $340 \mathrm{~m} \mu$, with NADPH and $\mathrm{NADH}$ as hydrogen donors and methemoglobin as hydrogen acceptor. Transketolase and transaldolase were assayed with a spectrophotometric determination of oxidized $\mathrm{NADH}$ as an index of the triosephosphate produced from pentose-5-phosphate and from fructose6-phosphate. Reduced glutathione stability was determined according to Beutler (15) in the presence of glucose $5 \times 10^{-3} \mathrm{M}$.

Enzyme determinations were not corrected for activity caused by leukocyte enzymes. Contamination of the erythrocyte preparation by leukocytes is estimated to be lower than $0.03 \%$ in hemolysates of the whole cell population $(6,16,17)$. Accordingly, we estimated that the degree of contamination by leukocytes had no detectable effect on the red cell enzyme assays.

Chemical determinations. Reduced glutathione contents were assayed by the method of Grunert and Philips (18). Hemoglobin concentrations were measured by pipetting a suitable quantity of hemolysate into $3 \mathrm{ml}$ of $0.4 \% \mathrm{NH}_{4} \mathrm{OH}$ and reading the optical density of the resulting solution in a spectrophotometer at $540 \mathrm{~m} \mu$.

Calculations. In experiments in which erythrocytes were separated on the basis of different osmotic resistance, "most resistant cells" are those unlysed after hemolysis with $0.30 \% \mathrm{NaCl}$ for 15 minutes at $0^{\circ} \mathrm{C}$; "least resistant cells" are those hemolyzed with $0.46 \%$ $\mathrm{NaCl}$ under the same conditions.

The number of cells was determined by hemolysis achieved by a given concentration of $\mathrm{NaCl}$, taking the extent of hemolysis in the water tube as equal to $100 \%$. In red blood cell separation by centrifugation, both the upper and lower fractions were $3 \%$ of the whole erythrocyte population (WEP).

In tables we expressed GSH as milligrams per 100 milliliters of packed erythrocytes ; the activities of glucose-6phosphate dehydrogenase, 6-phosphogluconate dehydrogenase, glutathione reductase, and methemoglobin re- ductase were expressed as the change in optical density per minute per gram of hemoglobin (OD per minute per gram $\mathrm{Hgb}$ ); transketolase and transaldolase activities were expressed as micromoles of oxidated NADH per hour and per gram of hemoglobin. Mean values and standard deviations (SD) are indicated on tables.

Reagents. Phosphopentose isomerase and phosphoketopentose epimerase were prepared according to Ashwell and Hickman (19). Hemoglobin was prepared from human blood according to Drabkin (20) and methemoglobin using $\mathrm{NaNO}_{2}$ to oxidate hemoglobin (21). Other substrates were acquired commercially. ${ }^{1}$

\section{Results}

1) Enzyme activities in normal erythrocytes. The data concerning enzyme activities in the whole erythrocyte population and in young and old cells of 18 normal subjects are reported in Table I (for cells separated by osmotic fragility) and in Table II (for cells separated by centrifugation).

Enzyme activities showed a marked difference between relatively old and young erythrocytes; the difference was more striking between fractions separated by osmotic lysis than between those separated by centrifugation. In agreement with data reported by Marks, Johnson, and Hirchberg (1) and by Marks and Gross (6), we found a big difference in glucose-6-phosphate dehydrogenase and 6-phosphogluconate dehydrogenase activities between young and old red blood cells. The mean values for the enzyme activity in the young cells exceeded values of the old cells for G-6-PD by factors of 8.5 and 1.7, respectively, for osmotic separation and centrifugation separation and of 5.3 and 1.5 for 6-P-GD. Corresponding factors were 4.5 and 1.4 for NADPH-dependent methemoglobin reductase and 4.2 and 1.8 for NADH-dependent methemoglobin reductase; such an augmentation in methemoglobin reductase activity for younger erythrocytes had already been suggested (22). There have been no previous observations in any population group of the alterations in transketolase and transaldolase activities as red cells age in vivo. Our findings indicate that the activities of these two enzymes are significantly higher in young compared to old cells by a factor

\footnotetext{
${ }^{1}$ Sigma Chemical Co., St. Louis, Mo. Enzymes for spectrophotometric determination purchased from C. F. Boehringer, Mannheim, Germany.
} 


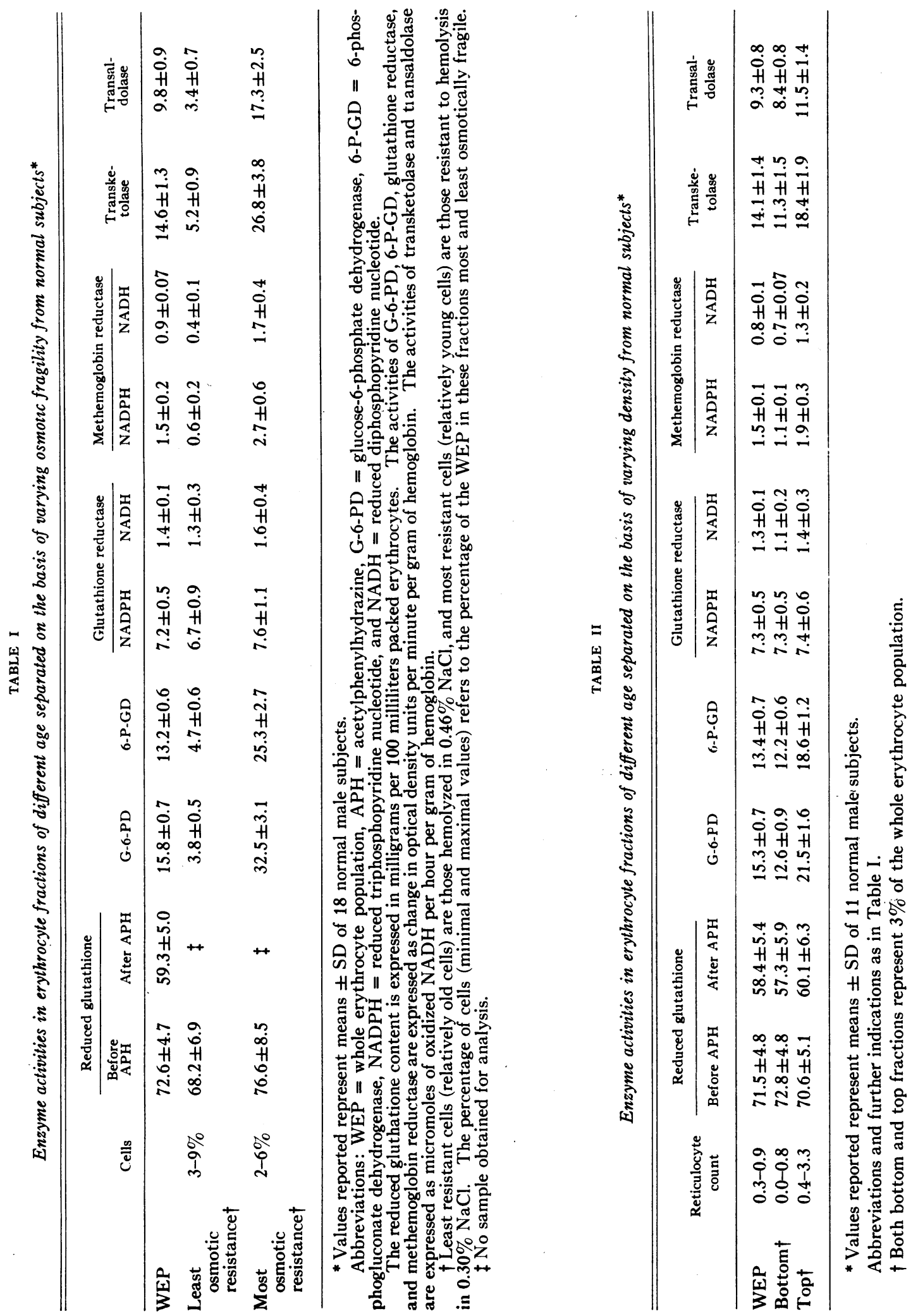


TABLE III

Enzyme activities in erythrocyte fractions of different age separated on the basis of varying osmotic fragility from fava bean-sensitive subjects*

\begin{tabular}{|c|c|c|c|c|c|c|c|c|c|c|c|}
\hline & \multirow[b]{2}{*}{ Cells } & \multicolumn{2}{|c|}{$\begin{array}{c}\text { Reduced glu- } \\
\text { tathione }\end{array}$} & \multirow[b]{2}{*}{ G-6-PD } & \multirow[b]{2}{*}{ 6-P-GD } & \multicolumn{2}{|c|}{$\begin{array}{l}\text { Glutathione } \\
\text { reductase }\end{array}$} & \multicolumn{2}{|c|}{$\begin{array}{l}\text { Methemoglobin } \\
\text { reductase }\end{array}$} & \multirow[b]{2}{*}{$\begin{array}{c}\text { Transke- } \\
\text { tolase }\end{array}$} & \multirow[b]{2}{*}{$\begin{array}{c}\text { Transal- } \\
\text { dolase }\end{array}$} \\
\hline & & $\begin{array}{c}\text { Before } \\
\text { APH }\end{array}$ & $\begin{array}{l}\text { After } \\
\text { APH }\end{array}$ & & & NADPH & $\overline{\mathrm{NADH}}$ & NADPH & NADH & & \\
\hline WEP & & $41.3 \pm 3.0$ & $8.1+0.9$ & $0.7 \pm 0.2$ & $13.4+0.6$ & $7.1 \pm 0.6$ & $1.5 \pm 0.2$ & $0.6+0.07$ & $0.3 \pm 0.04$ & $24.3 \pm 2.1$ & $15.4 \pm 1.2$ \\
\hline Least & $2-8 \%$ & $29.6 \pm 5.8$ & $\ddagger$ & $0.2 \pm 0.05$ & $4.3 \pm 0.6$ & $6.5 \pm 0.8$ & $1.3 \pm 0.3$ & $0.3 \pm 0.07$ & $0.2 \pm 0.03$ & $8.6 \pm 1.8$ & $5.2 \pm 1.5$ \\
\hline Most & $2-7 \%$ & $56.5 \pm 9.4$ & $\ddagger$ & $1.1 \pm 0.3$ & $24.8 \pm 2.5$ & $8.0 \pm 1.3$ & $1.7 \pm 0.4$ & $1.6 \pm 0.5$ & $1.0 \pm 0.3$ & $38.4 \pm 4.5$ & $27.2 \pm 3.7$ \\
\hline
\end{tabular}

* Values reported represent means \pm SD of 16 fava bean-sensitive male subjects.

of 5.1 for both TK and TA when cells are separated by osmotic hemolysis and of 1.6 for TK and 1.3 for TA when cells are separated by the centrifugation techniques.

No significant difference was found, as already described by Prankerd (23), in GSH contents between cells of different ages. GSH stability showed a similar behavior when incubated with acetylphenylhydrazine. No significant variations have been found in cell fractions with respect to glutathione reductase.

2) Enzyme activities in subjects with a past history of favism. Similar to erythrocytes of subjects with normal levels of glucose-6-phosphate dehydrogenase, aging in vivo is associated with significant decrease in activities of all the enzymes studied with the exception of methemoglobin reductase. In striking contrast to the findings with the red cells of normal subjects, aging in vivo of erythrocytes with glucose-6phosphate dehydrogenase deficiency is associated with a decrease in reduced glutathione content and stability (Tables I to IV).

The mean values for GSH content in the younger cells exceeded values in the older ones by factors of 1.9 for osmotic separation and 1.4 for separation by centrifugation. Much more remarkable is the increase of GSH stability in young erythrocytes, where the value of the centrifugation fraction was 2.3 times higher than old ones. Determinations of GSH could not be performed on cells separated by osmotic hemolysis. In fractions of both young and old cells, glucose-6-phosphate dehydrogenase activity was extremely low, although there was a definite difference between young and old cells (Tables I to IV). The findings with respect to the glucose6-phosphate dehydrogenase activity were similar in both normal and favic subjects (Tables I to IV).

$\mathrm{NADPH}-$ and NADH-dependent methemoglobin reductase showed a marked increase in younger cells (Tables I to IV). In previous studies (13), we found that methemoglobin reductase activity is constantly low in the WEP of fava bean-sensitive subjects. The present study demonstrates that this decrease is detectable both in young and old erythrocytes. The WEP and the young and old cells of favic and normal subjects decrease at a similar percentage (Tables I to IV).

TK and TA activities decrease markedly as red cells age in vivo in both normal and favic subjects (Tables I to IV). In comparison with

TABLE IV

Enzyme activities in erythrocyte fractions of different age separated on the basis of varying density from fave bean-sensitive subjects*

\begin{tabular}{|c|c|c|c|c|c|c|c|c|c|c|c|}
\hline & \multirow[b]{2}{*}{$\begin{array}{l}\text { Reticulocyte } \\
\text { count }\end{array}$} & \multicolumn{2}{|c|}{ Reduced glutathione } & \multirow[b]{2}{*}{ G-6-PD } & \multirow[b]{2}{*}{ 6-P-GD } & \multicolumn{2}{|c|}{$\begin{array}{l}\text { Glutathione } \\
\text { reductase }\end{array}$} & \multicolumn{2}{|c|}{$\begin{array}{l}\text { Methemoglobin } \\
\text { reductase }\end{array}$} & \multirow[b]{2}{*}{$\begin{array}{l}\text { Transke- } \\
\text { tolase }\end{array}$} & \multirow[b]{2}{*}{$\begin{array}{c}\text { Transal- } \\
\text { dolase }\end{array}$} \\
\hline & & $\begin{array}{l}\text { Before } \\
\text { APH }\end{array}$ & $\begin{array}{l}\text { After } \\
\text { APH }\end{array}$ & & & N.ADPH & NADH & NADPH & NADH & & \\
\hline WEP & $0.4-1.1$ & $42.5 \pm 3.3$ & $8.5 \pm 0.9$ & $0.8 \pm 0.2$ & $13.9 \pm 0.7$ & $7.2 \pm 0.6$ & $1.5 \pm 0.3$ & $0.07 \pm 0.7$ & $0.4 \pm 0.04$ & $25.1 \pm 2.4$ & $15.2 \pm 1.3$ \\
\hline Bottom & $0.1-0.7$ & $37.4 \pm 3.2$ & $7.6 \pm 1.2$ & $0.6 \pm 0.2$ & $11.8 \pm 0.8$ & $7.2 \pm 0.7$ & $1.6 \pm 0.4$ & $0.5 \pm 0.07$ & $0.3 \pm 0.04$ & $20.6 \pm 2.1$ & $13.8 \pm 1.2$ \\
\hline Top & $0.3-4.1$ & $51.2 \pm 4.1$ & $17.8 \pm 2.7$ & $0.9 \pm 0.3$ & $16.4 \pm 1.2$ & $7.4 \pm 0.6$ & $1.4 \pm 0.3$ & $1.0 \pm 0.2$ & $0.5 \pm 0.06$ & $29.2 \pm 3.0$ & $18.1 \pm 1.9$ \\
\hline
\end{tabular}

*Values reported represent the means $\pm \mathrm{SD}$ of 10 fava bean-sensitive male subjects. 
normal subjects, the red cells of favic patients have higher activities of both TK and TA demonstrable in studying the WEP or separated young and old erythrocyte fractions. We have previously suggested (24) that the increased activities of TK and TA in sensitive red blood cells could be a compensatory mechanism enablirg these cells to synthesize pentose phosphate, although they lack the oxidative steps of the pentose phosphate pathway. Indeed the synthesis of pyridinenucleotides, one of the most efficient methods of evaluating pentose phosphate synthesis (25), is completely normal in fava beansensitive erythrocytes (24).

3) Enzyme activities of fava bean-sensitive erythrocytes during the hemolytic and posthemolytic periods. Observations on the alterations in red cell enzymes after hemolytic crisis in subjects with G-6-PD deficiency have been limited to determination of G-6-PD and GSH levels, and these only in affected Negro subjects $(5,7,26$, 27).

It is increasingly difficult to observe patients during an acute hemolytic crisis caused by fava bean, owing to the improved public health service measures. Our studies included observations on 8 subjects and yielded quite constant results. All patients studied had severe hemolytic episodes, as indicated by erythrocyte counts performed 2 to 12 hours after onset of acute clinical symptoms that were ascertained from the anamnesis.

The content and stability of GSH during the acute episode, even if slightly increased in comparison with the WEP of subjects with a past history of favism, were constantly very low (Table V). G-6-PD activity was markedly deficient in all subjects; 6-P-GD, TK, TA, and methemoglobin reductase activities were all increased. During the hemolytic crisis, glutathione reductase did not vary. These findings are consistent with the alterations in activity of enzymes with aging of the cells in patients without crisis. Further evidence for a younger than normal mean cell age of the red cells is that the percentage of unlysed cells in $0.30 \% \mathrm{NaCl}$ was increased (compare Tables III and VI). Consistent with these findings is the fact that the ratios between the enzyme activities in the younger and the older cells are lower during the

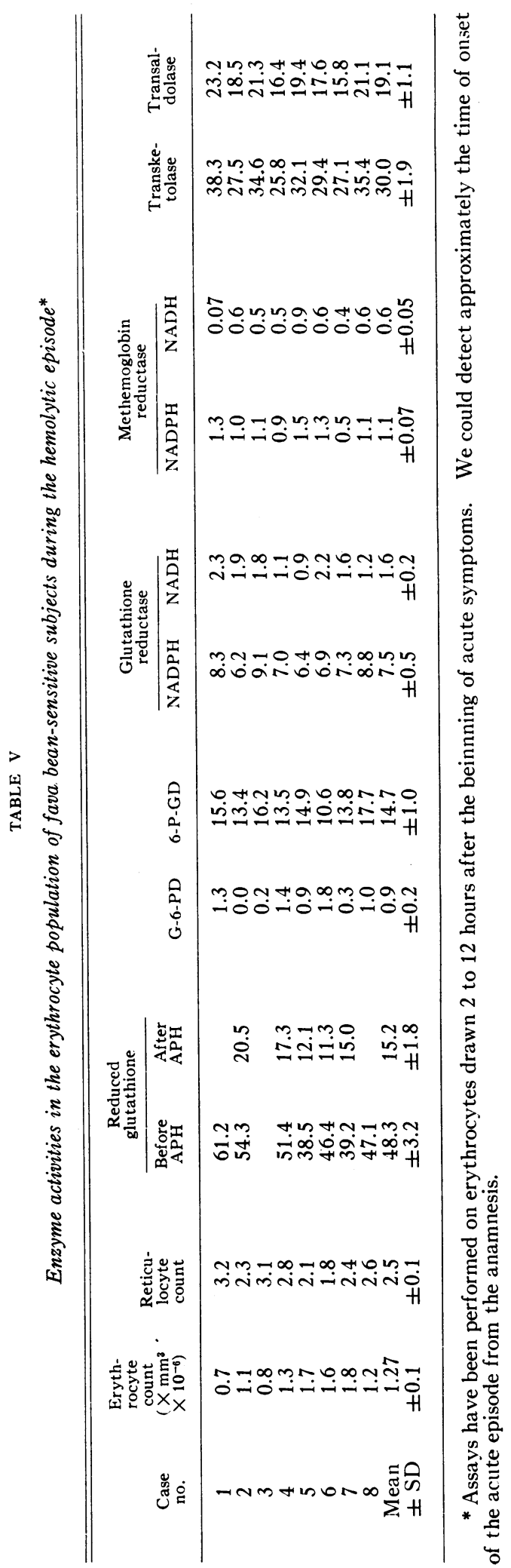


TABLE VI

Enzyme activities in the whole erythrocyte population of fava bean-sensitive subjects in the posthemolytic period*

\begin{tabular}{|c|c|c|c|c|c|c|}
\hline & \multicolumn{6}{|c|}{ Days after crisis } \\
\hline & 0 & 3 & 6 & 9 & 12 & 15 \\
\hline Reticulocyte count & $2.3 \pm 0.2$ & $24.6 \pm 2.7$ & $10.2 \pm 1.1$ & $8.8 \pm 1.0$ & $5.6 \pm 0.4$ & $4.2 \pm 0.3$ \\
\hline $\begin{array}{l}\text { Reduced } \\
\text { glutathione }\end{array}$ After APH & $\begin{array}{l}48.3 \pm 2.5 \\
14.7 \pm 1.0\end{array}$ & $\begin{array}{l}59.3 \pm 3.7 \\
30.8 \pm 2.6\end{array}$ & $\begin{array}{l}75.4 \pm 5.4 \\
57.2 \pm 5.1\end{array}$ & $\begin{array}{l}76.6 \pm 5.8 \\
58.4 \pm 4.9\end{array}$ & $\begin{array}{l}75.2 \pm 5.5 \\
50.2 \pm 5.0\end{array}$ & $\begin{array}{l}68.6 \pm 5.6 \\
29.7 \pm 3.8\end{array}$ \\
\hline G-6-PD & $1.1 \pm 0.2$ & $1.1 \pm 0.2$ & $0.9 \pm 0.2$ & $1.2 \pm 0.3$ & $0.7 \pm 0.1$ & $0.9 \pm 0.2$ \\
\hline $\begin{array}{l}\text { Methemoglobin } \\
\text { reductase }\end{array}$ NADPH & $\begin{array}{l}1.1 \pm 0.1 \\
0.6 \pm 0.1\end{array}$ & $\begin{array}{l}2.0 \pm 0.3 \\
1.2 \pm 0.2\end{array}$ & $\begin{array}{l}1.9 \pm 0.3 \\
1.3 \pm 0.3\end{array}$ & $\begin{array}{l}1.6 \pm 0.3 \\
0.9 \pm 0.2\end{array}$ & $\begin{array}{l}1.6 \pm 0.2 \\
0.9 \pm 0.2\end{array}$ & $\begin{array}{l}1.4 \pm 0.2 \\
0.7 \pm 0.1\end{array}$ \\
\hline Transketolase & $28.6 \pm 1.5$ & $37.4 \pm 2.3$ & $35.2 \pm 2.5$ & $32.5 \pm 2.2$ & $30.6 \pm 1.9$ & $29.1 \pm 2.1$ \\
\hline Transaldolase & $17.3 \pm 0.9$ & $25.2 \pm 1.5$ & $21.4 \pm 1.1$ & $19.5 \pm 1.4$ & $17.8 \pm 1.3$ & $16.9 \pm 1.3$ \\
\hline
\end{tabular}

* Values reported are the means $\pm \mathrm{SD}$ of 4 subjects (Cases $4,5,6$, and 7 of Table V).

hemolytic episode than in the nonhemolytic period.

Four cases (no. 4-7) were given no blood transfusion but had severe anemia. Between the third and the fifteenth days after onset of the crisis, the content and stability of GSH and the activities of G-6-PD, methemoglobin reductase, TK, and TA were determined (Table VI). During the posthemolytic period, no increase in red cell G-6-PD activity was detectable, although a consequent increase in the activities of methemoglobin reductase, TK, and TA occurred. The increment in activities of these latter enzymes most likely reflects the young mean age of the cell population during this period. As in our previous work (28), after acute hemolytic crisis, GSH contents and GSH stability show an increase and reach normal values by the sixth day after the crisis. During the twelfth day the GSH stability begins to decrease, and at the fifteenth day, it returns to abnormally low values. $\mathrm{GSH}$ content, however, is still within the normal range at this time. On admission to the hospital of 5 cases (no. 2, 4, 5, 6, 7), we were able to obtain an amount of blood sufficient to separate young and old cells by the osmotic fragility method. The results obtained are similar to those obtained in subjects with a past history of favism but not in hemolytic crisis (compare Tables III and VI). Glutathione reductase did not vary with the age of cells, but other enzyme activities changed as cells aged in vivo.

\section{Discussion}

In the present study of Sardinian subjects with G-6-PD deficiency and favism, without any detectable increase in G-6-PD activity a striking increase in GSH content and GSH stability occurred during posthemolytic periods. Several aspects of this finding are of particular interest in considering the problem of G-6-PD deficiency.

1) The absence of a rise in G-6-PD activity among these Sardinian subjects contrasts with

TABLE VII

Enzyme activities in erythrocyte fractions of different age separated on the basis of varying osmotic fragility from fava bean-sensitive subjects during the hemolytic episode*

\begin{tabular}{|c|c|c|c|c|c|c|c|c|c|c|}
\hline & \multirow[b]{2}{*}{ Cells } & \multirow{2}{*}{$\begin{array}{c}\text { Reduced } \\
\text { glutathione }\end{array}$} & \multirow[b]{2}{*}{ G-6-PD } & \multirow[b]{2}{*}{ 6-P-GD } & \multicolumn{2}{|c|}{$\begin{array}{l}\text { Glutathione } \\
\text { reductase }\end{array}$} & \multicolumn{2}{|c|}{$\begin{array}{l}\text { Methemoglobin } \\
\text { reductase }\end{array}$} & \multirow{2}{*}{$\begin{array}{l}\text { Transke- } \\
\text { tolase }\end{array}$} & \multirow{2}{*}{$\begin{array}{c}\text { Transal- } \\
\text { dolase }\end{array}$} \\
\hline & & & & & NADPH & NADH & NADPH & NADH & & \\
\hline WEP & & $45.9 \pm 3.6$ & $0.9 \pm 0.2$ & $13.2 \pm 0.7$ & $6.7 \pm 0.5$ & $1.5 \pm 0.2$ & $1.0 \pm 0.07$ & $0.6 \pm 0.05$ & $28.4 \pm 1.2$ & $17.5 \pm 0.7$ \\
\hline Least $†$ & $2-5 \%$ & $\ddagger$ & $0.6 \pm 0.2$ & $5.8 \pm 0.7$ & $6.3 \pm 0.9$ & $1.6 \pm 0.3$ & $0.6 \pm 0.1$ & $0.4 \pm 0.07$ & $12.8 \pm 1.9$ & $9.2 \pm 1.8$ \\
\hline Most $†$ & $8-23 \%$ & $64.2 \pm 10.9$ & $1.3 \pm 0.4$ & $24.1 \pm 2.6$ & $7.1 \pm 1.2$ & $1.6 \pm 0.4$ & $2.0 \pm 0.4$ & $1.4 \pm 0.3$ & $41.8 \pm 5.2$ & $30.4 \pm 4.4$ \\
\hline
\end{tabular}

* Values reported are the means $\pm \mathrm{SD}$ of 5 subjects (Cases $2,4,5,6$, and 7 of Table $\mathrm{V}$ ).

† Least resistant cells are those hemolyzed in $0.40 \% \mathrm{NaCl}$; on the other hand, in corresponding experiments on normal subjects and on subjects with past history of favism, least resistant cells are those hemolyzed in $0.46 \% \mathrm{NaCl}$.

$\ddagger$ No sample obtained for analysis. 
the observations among the Negro population after primaquine-induced hemolytic crisis. This difference is consistent with previous observations and with the present data, indicating a significantly smaller change in affected Negroes than in affected Caucasians of G-6-PD activity in young compared to old erythrocytes. These data, therefore, provide further evidence for a heterogeneity in the biochemical expression of G-6-PD among different population groups. This evidence of heterogeneity is particularly interesting because of its possible relevance to the markedly more severe clinical features of favism among Sardinian than the drug-induced hemolytic crisis among Negro subjects.

2) That GSH content and stability return towards control levels in the posthemolytic period in the absence of an increase in G-6-PD activity suggests that the rate of the G-6-PD-catalyzed $\mathrm{NADPH}$ production is not the primary factor determining the GSH levels in these cells. It is difficult to advance a hypothesis to explain the mechanism by which GSH contents go back to normal values because the control of equilibrium reaction of oxidized and reduced forms of glutathione is complicated and not yet fully understood. In these favic subjects the increase in GSH clearly cannot be accounted for by an augmentation in G-6-PD activity. Further, the question is raised of whether the increased resistance of young cells to hemolysis in the posthemolytic period is always related to the activity of G-6-PD.

Several authors $(8,29,30)$ and we also (31, 32 ) have described some cases of subjects whose red cells showed a normal G-6-PD and a pathological GSH and vice versa; according to one hypothesis, the alterations of GSH could be related not only to G-6-PD but also to other metabolic defects. The dissociation between G-6-PD deficiency and GSH defect in younger erythrocytes of fava bean-sensitive subjects, as pointed out in the present paper, is consistent with such a hypothesis.

The implication of our results based on the studies with favic subjects may not be generalized to all subjects with G-6-PD deficiency. Fava bean-induced anemias and drug-induced anemias, although considered together on the basis of the G-6-PD deficiency common to both, could be quite different in biochemical, genetic, and clinical aspects. Some differences concerned with G-6-PD deficiency have already been detected. In Negroes the defect has been found only in erythrocytes and lens tissues, but in Sardinian and Jewish subjects it is present in other tissues (33-39). The enzyme purified from erythrocytes of Negroes shows no abnormal characteristics, whereas in Caucasians and in an Italian family differences in the properties of the catalytic site are well known (40).

\section{Summary}

1. The relationship between age and metabolic activities in human erythrocytes was studied in 18 normal subjects and in 24 Sardinian subjects, of whom 16 had a past history of favism and 8 had an acute hemolytic episode after a fava bean ingestion. Relatively older and younger cells were separated on the bases of their varying osmotic fragility and their varying density. In these fractions and in the whole erythrocyte population the content and stability of reduced glutathione and the activities of glucose-6-phosphate dehydrogenase, 6-phosphogluconate dehydrogenase, glutathione reductase, methemoglobin reductase, transketolase, and transaldolase were determined.

2. In younger erythrocytes of normal subjects, all enzymes studied showed higher activities except glutathione reductase. The content and the stability of reduced glutathione did not vary with age.

3. In subjects with a past history of favism all enzyme activities except glutathione reductase and the content and stability of reduced glutathione vary with age. In all fractions the glucose-6-phosphate dehydrogenase and methemoglobin reductase activities are extremely low in comparison with normal red blood cells.

4. The glucose-6-phosphate dehydrogenase activity is always extremely low and does not vary. In the posthemolytic period the content and stability of reduced glutathione reach control levels during the first days after crisis and afterwards go back to abnormal levels. The activities of methemoglobin reductase, transketolase, and transaldolase increase during the first days after crisis and decrease afterwards back to values we 
found in subjects with a past history of favism (that is, in the nonhemolytic period).

5. These data are discussed in terms of the heterogeneity of the glucose-6-phosphate dehydrogenase deficiency in different population groups and the role of glucose-6-phosphate dehydrogenase in the maintenance of the level of erythrocyte reduced glutathione.

\section{References}

1. Marks, P. A., A. B. Johnson, and E. Hirchberg Effect of age on the enzyme activity in erythrocytes. Proc. nat. Acad. Sci. (Wash.) 1958, 44 529.

2. Alving, A. S., A. R. Tarlov, G. Brewer, P. E. Karlson, R. W. KellerMeyer, and W. K. Long. Glucose-6-phosphate dehydrogenase deficiency: some biological implications. Trans. Ass. Amer. Phycns 1960, 73, 80.

3. Beutler, E., R. J. Dern, and A. S. Alving. The hemolytic effect of primaquine. IV. The relationship of cell age to hemolysis. J. Lab. clin. Med. 1955, 44, 439.

4. Beutler, E. The hemoiytic effect of primaquine and related compounds: a review. Blood 1959, 14, 103.

5. Marks, P. A. Aspects biochimiques du vieillissement du globulg rouge et de l'anémie hemolitique d'origine medica menteuse. Nouv. Rev. franc. Hémat. 1961, 1, 900.

6. Marks, P. A., and R. T. Gross. Erythrocyte glucose6-phosphate dehydrogenase deficiency: evidence of difference between Negroes and Caucasians with respect to this genetically determined trait. J. clin. Invest. 1959, 38, 2253.

7. Flanagan, C. L., S. L. Schrier, P. E. Carson, and A. S. Alving. The hemolytic effect of primaquine. VIII. The effect of drug administration on parameters of primaquine sensitivity. J. Lab. clin. Med. 1958, 51, 600.

8. Larizza, P., P. Brunetti, F. Grignani, and S. Ventura. L'individualità bio-enzimatica dell'eritrocita favico. Sopra alcune anomalie biochimiche ed enzimatiche delle emazie nei pazienti affetti da favismo e nei loro familiari. Haematologica 1958, 43, 205.

9. Marks, P. A., and A. B. Johnson. Relationship between the age of human erythrocytes and their osmotic resistance: a basis for separating young and old erythrocytes. J. clin. Invest. 1958, 37, 1542.

10. Kornberg, A., and B. L. Horecker. Glucose-6-phosphate dehydrogenase in Methods in Enzymology, S. P. Colowick and N. O. Kaplan, Eds. New York, Academic Press, 1957, vol. 1, p. 323.

11. Horecker, B. L., and P. Z. Smyrniotis. Phosphogluconic acid dehydrogenase from yeast. J. biol. Chem. 1951, 193, 371.
12. Glock, G. E., and P. McLean. Further studies on the properties and assay of glucose 6-phosphate dehydrogenase and 6-phosphogluconate dehydrogenase of rat liver. Biochem. J. 1953, 55, 400.

13. Bonsignore, A., G. Fornaini, G. Segni, and A. Fantoni. Glutathione reductase and methaemoglobin reductase in erythrocytes of human subjects with favism history. Ital. J. Biochem. 1960, 9, 345.

14. Bonsignore, A., G. Fornaini, G. Segni, and A. Seitung. Transketolase and transaldolase reactions in the erythrocytes of human subjects with favism history. Biochem. biophys. Res. Commun. 1961, 4, 147.

15. Beutler, E. The glutathione instability of drug sensitive red cells. A new method for the in vitro detection of drug sensitivity. J. Lab. clin. Med. 1957, 49, 84.

16. Beck, W. S. The control of leukocytes glycolysis. J. biol. Chem. 1958, 232, 251.

17. Fornaini, G., G. Leoncini, and P. Segni. Unpublished results.

18. Grunert, R. R., and P. H. Philips. A modification of the nitroprusside method of analysis for glutathione. Arch. Biochem. 1951, 30, 217.

19. Ashwell, G., and J. Hickman. Enzymatic formation of xilulose-5-phosphate from ribose-5-phosphate in spleen. J. biol. Chem. 1957, 226, 65.

20. Drabkin, D. L. A simple technique for a large scale crystallization of human oxyhemoglobin. Isomorphous transformations of hemoglobin and myoglobin in the crystalline state. Arch. Biochem. 1949, 21, 224.

21. Austin, J. H., and D. L. Drabkin. Spectrophotometric studies of methaemoglobin. III : Methaemoglobin from oxyhemoglobin in presence of $\mathrm{NaNO}_{2}$. J. biol. Chem. 1935, 112, 67.

22. Lohr, G. W., H. D. Waller, O. Karges, B. Schlegel, and A. A. Muller. Zur Biochemie der Alterung menschlicher Erythrocyten. Klin. Wschr. 1958, 36, 1008 .

23. Prankerd, T. A. J. The ageing of red cells. J. Physiol. 1958, 143, 325.

24. Bonsignore, A., G. Fornaini, G. Segni, and A. Fantoni. Biosynthesis of pyridine coenzymes in erythrocytes from subject with favism history. Ital. J. Biochem. 1961, 10, 212.

25. Hiatt, H. H., and J. Lareau. Studies of ribose metabolism. VIII. Pathways of ribose biosynthesis in vivo and in vitro in rat, mouse and human tissues. J. biol. Chem. 1960, 235, 1241.

26. Szeimberg, A., Y. Asher, and C. Sheba. Studies on glutathione stability in erythrocytes of cases with past history of favism or sulfa-drug-induced hemolysis. Blood 1958, 13, 348.

27. Dawson, J. P., W. W. Thayer, and J. F. Desforges. Acute hemolytic anemia in the newborn infant due to nephtalene poisoning. Report of two cases with investigation into the mechanism of the disease. Blood 1958, 13, 1113. 
28. Bonsignore, A., G. Fornaini, G. Segni, and A. Seitun. Comportamento di alcuni enzimi eritrocitari di un soggetto favico nel periodo postemolitico. Boll. Soc. ital. Biol. sper. 1960, 36, 1215.

29. Szeimberg, A., C. Sheba, and A. Adam. Enzymatic abnormality in erythrocytes of a population sensitive to vicia fava or drug induced hemolytic anemia. Nature (Lond.) 1958, 181, 1256.

30. Gross, R. T., R. E. Hurwitz, and J. Beasley. Further studies in the hereditary biochemical lesion in certain drug induced hemolytic anemias (abstract). Clin. Res. 1958, 6, 73.

31. Fornaini, G., and E. Bianchini. Comportamento di alcune attività enzimatiche eritrocitarie in tre casi di anemia emolitica ereditaria non sferocitica. Boll. Soc. ital. Biol. sper. 1961, 37, 392.

32. Fornaini, G., E. Bianchini, G. Leoncini, and A. Fantoni. Metabolic aspects of erythrocytes in congenital non spherocitic haemolitic anaemia. Brit. J. Haemat. 1964, 10, 23.

33. Ramot, B., A. Szeinberg, A. Adam, C. Sheba, and D. Gafni. A study of subjects with erythrocyte glucose-6-phosphate dehydrogenase deficiency: investigation of platelet enzymes. J. clin. Invest. 1959, 38, 1659.

34. Ramot, B., S. Fisher, A. Szeinberg, A. Adam, C. Sheba, and D. Gafni. A study of subjects with erythrocyte glucose-6-phosphate dehydrogenase de- ficiency. II. Investigation of leukocyte enzymes. J. clin. Invest. 1959, 38, 2234.

35. Ramot, B., C. Sheba, A. Adam, and J. Ashekenasi. Erythrocyte glucose-6-phosphate dehydrogenase deficient subjects: enzyme level in saliva. Nature (Lond.) 1960, 285, 931.

36. Marks, P. A., and R. T. Gross. Further characterization of the enzymatic defect in erythrocyte glucose-6-phosphate dehydrogenase deficiency: a genetically determined trait (abstract). J. clin. Invest. 1959, 38, 2023.

37. Marks, P. A., J. Banks, and R. T. Gross. Glucose-6phosphate dehydrogenase thermostability in leukocytes of Negroes and Caucasians with erythrocyte deficiency of this enzyme. Biochem. biophys. Res. Commun. 1959, 1, 199.

38. Panizon, F. Dimostrazione dell'anomalia enzimatica nel fegato di soggetti condifetto eritrocitario di glucose-6-fosfato deidrogenasi. Boll. Soc. ital. Biol. sper. 1959, 36, 106.

39. Panizon, F. Studio dell'attività enzimatica della mucosa digiunale in soggetti con glucoso-6-fosfato deidrogenasi-penia eritrocitaria. Studi sassaresi 1961, 39, 210.

40. Marks, P. A., J. Banks, and R. T. Gross. Genetic heterogeneity of glucose-6-phosphate dehydrogenase deficiency. Nature (Lond.) 1962, 194, 454. 